Regular Research Article

\title{
India in international climate governance: Through soft power from REDD to REDD+ policy in favor of relative gains
}

\author{
Swati Negi ${ }^{1}$ and Lukas Giessen ${ }^{2,3, *}$ \\ 1 Institute of Terrestrial Ecosystem, Department of Environmental System Sciences, Swiss Federal Institute \\ of Technology, (ETH) 8092 Zürich, Switzerland; swati.negi@usys.ethz.ch (SN) \\ 2 Chair of Forest and Nature Conservation Policy, University of Göttingen, \\ 3 European Forest Institute (EFI), Bonn Office \\ * Corresponding author: Lukas.Giessen@efi.int
}

\begin{abstract}
This paper seeks to examine India's role in the politics of a specific climate change mitigation policy called "Reducing emissions from deforestation and forest degradation, and enhancing forest carbon stocks in developing countries (REDD+)". It explores India's strategic behaviour towards the development of REDD policy. The paper argues that India had pushed for the remodelling of the global REDD negotiations by expanding its scope to conservation activities, which entails more direct benefits for India. This is largely due to differences in India's rates of forest cover and deforestation as compared to high forest - high deforestation countries such as Brazil and Indonesia. To substantiate its argument, the paper uses the main underpinnings of relative gains theory in international relations and applies them toward interpreting India's behaviour in negotiating REDD+ at global level. Further, the paper analyses the Indian strategies used to remodel the REDD mechanism using insights from soft power theory and its more recent amendments. Thematic analysis of the REDD-relevant documents as well as exploratory expert interviews have been employed for showing India's proactive role in the politics of REDD+. It is concluded that India indeed played a central role in critical past decisions, which lead to re-shaping REDD due to relative gains concerns and mainly by means of soft power strategies.
\end{abstract}

Keywords: REDD+; India; international governance; relative gains; soft power; forest cover change; forest management; forest policy; deforestation rates; forest carbon stocks

\section{Introduction}

Climate change has strongly dominated international forest and related environmental governance since the past 30 years (Singer and Giessen, 2017; Sahide et al., 2015; Giessen, 2013; Giessen et al., 2014). In the recent times, the clout of emerging economies such as Brazil, Russia, India and China (the BRICs) have come to the forefront of the climate change negotiations (Tan, 2014) and with the rise of the BRICs, the negotiation power in the system of climate governance has become more diffused (Jang et al., 2016).

India, in particular, has emerged as one of the key actors in global climate politics under the United Nations Framework Convention on Climate Change (UNFCCC) (Vihma, 2011; Atteridge et al., 2012). India's per capita GHG emissions are among the lowest in the world however, when accounted in total tonnes, India stands tall at being the fourth largest GHG emitter globally (Olivier et al., 2017). Given this dichotomy, India has very proactively positioned itself around the climate change discourse (Atteridge et al., 2012).

Within global climate governance and among all other negotiations, a forest-specific mechanism has been negotiated as a central component of a post-Kyoto climate agreement (Lövbrand, 2009; Humphreys, 2006; 2008; Nijnik and Bizikova, 2008). It is called "Reducing emissions from deforestation and forest degradation, and enhancing forest carbon stocks in developing 
countries $\left(R E D D+{ }^{1}\right) "$. The evolving REDD+ programme provides positive financial incentives to help developing countries reduce their deforestation rates (Karsenty and Ongolo, 2012; Schoene and Bernier, 2011; Pistorius et al. 2012). REDD+ can be seen as an offset scheme within carbon markets that will generate carbon credits. These credits, in turn, are supposed to compensate for carbon emissions and could be used (mainly by industrialised countries) to meet emission targets and to be traded in carbon markets. The REDD+ mechanism in its course of evolvement has witnessed many stages of development among which the most significant shift was marked by a reformulation of a former REDD mechanism (Reducing emissions from deforestation and forest degradation) to the REDD+ mechanism (Reducing emissions from deforestation and forest degradation and enhancing forest carbon stocks in developing countries) (Humphreys, 2008). India is said to have played a proactive role in bringing this shift in the REDD regime (Sud et al., 2012). Against this background, we make an attempt to analyse the motivation for India to become a key player in REDD negotiations at the intersection of global forest and climate politics. The paper also aims at understanding the strategies adopted by India for expanding the scope of REDD to compensate for forest conservation activities.

This article largely follows a neorealist line of argumentation suggesting that it is the selfinterests of a state that makes it concerned about the benefits it can extract from global agreements in comparison to the competing states, thus accumulating and exerting power in the pursuit of their own interests (Grieco, 1988). With this paper, we aim to contribute to the literature on global forestrelated climate politics which has so far ignored the relative gains perspective to understand the cooperation among countries.

The paper is guided by two core prepositions derived from the theoretical accounts of neorealism, which are discussed in section 2 . The assumptions are:

- India, during the REDD negotiations, acted responsive to the relative gains concern associated with REDD and exhibited relative-gain seeking behaviour in the negotiations by strongly advocating for adding the favourable notion of "plus" to the global agenda and REDD diplomacy.

- India used soft power strategies to achieve its goal of remodelling REDD into REDD+.

\section{Theoretical propositions}

\subsection{Relative gains theory and its relevance in global REDD politics}

In recent times, climate change and related REDD issues have become high-politics (Motaal, 2010) as opposed to low politics, under which all other environmental issues may be subsumed (Willets, 2001). This is reflected by the inclusion of climate issues in the high level segments of COPs, G-8+5 and G-20 negotiations (Volger and Stephan, 2009). Nation-states increasingly behave in a more realist manner with regard to climate change as a global issue.

The issue of climate change has made its way up to the level of high-politics in the international system (Volger and Stephan, 2009) because of its impact not only on most developing countries but also on businesses and national economies (Willets, 2001). Thus, owing to the high politics nature of climate change, participating governments are likely to use a realist approach to secure their own interests while engaging in the discourse (Morgenthau, 1956). From a neo-realist perspective, states are inherently inclined to strive for relative advantage against other states on the international scene (Luttwak, 1990). Although a realist state is expected to focus on its own interest in any cooperation or collaboration with other countries, it not only focuses on its absolute gain (Mosher, 2003), but is also concerned about the gains of the other states involved in the co-operation, as any relative gain to other states may threaten a state's status in an international system (Keohane, 1998). Neo-realist scholars argue that this concern with relative gain is significant enough to inhibit international co-operation to a great extent (Grieco, 1988; Powell, 1991). However, Snidal (1991a) argues that states sometimes do exhibit relative gain-seeking behaviour, which does not necessarily have a significant general inhibiting effect on international cooperation.

1 Later in the text, "plus" is used as interchangeable with "+" 
Under relative gain-seeking behaviour, a state tends to limit the range of viable cooperative agreements and is reluctant to co-operate because no state will accept deals that provide disproportionately greater benefits to others (Snidal, 1991a). This argument is supported by the conflict between Brazil and India in the context of REDD+. Both states held extreme positions during the REDD negotiations at the COP- $15^{2}$ summit because there was a clear conflict of interest. REDD was initially introduced to compensate countries with high deforestation rates such as e.g. Brazil and Indonesia. However, with the inclusion of "plus" in the acronym REDD, it is more likely that REDD funds will be used to reward countries that have managed to maintain and enhance their carbon stocks (for e.g. India and China), which would significantly dwarf the amount of funds generated for halting deforestation in the first place (Potvin and Bovarnik, 2008).

Snidal (1991b, similar Wibowo and Giessen, 2015 for REDD+ in Indonesia, Giessen and Sahide 2017 on ASEAN forest and environmental policy) states that if distribution is the main relative-gain concern, then states will alter the terms of a cooperative agreement. In case of REDD, India did just that by putting the "plus" on the REDD agenda. The relative gains in the REDD context include monetary benefits in the form of REDD funds and the underlying goal of India associated with REDD politics (that is, enhancing its potential to emerge as a leader in global climate politics by showing its newly acquired power in world politics and changing its image from that of a deal-breaker to a deal-maker in climate change politics).

\subsection{Soft power theory and its relevance in REDD plus policy discourse}

The broad definition of soft power comes from international relations theory and refers to accomplishing international aims through persuasion and co-option (Vibert, 2008). The soft power theory has clearly become a growth point in research of international relations (Breslin, 2011). Joseph Nye (1990) first coined the term and defined it as "the ability to get what you want through attraction rather than coercion or payments... Soft power arises from the attractiveness of a country's culture, political ideals, and policies." (Nye, 2004a : p.12)

Nye (2004b) argues that a state's soft power refers to its ability to achieve its goals in an international system through persuasion, primarily via political ideas and norms and co-option, rather than using "hard" military power.

Guenn Lee (2009), however, expanded Nye's soft power definition and took the concept beyond the mere distinction between coercive (hard) power with co-optive (soft) power. Instead, he emphasised the use of non-material 'soft resources' to generate soft power, which, he claimed, can be both co-optive and coercive, depending on the use of soft resources.

Another power concept put forth in the field of forest policy studies is actor-centred power (Krott et al., 2014), according to which the power a political actor possesses can empirically be observed in form of dominant information, (dis-)incentives, and coercion through the threat or use of force. The concept has recently been further developed, esp. regarding the developments of power dynamics over time as well as issue-specific power resources as opposed to more general power concepts from international relations (Prabowo et al., 2016; 2017; Maryudi and Sahide, 2017; Rahman et al., 2016; 2018; Rahman and Giessen, 2016; Giessen et al., 2016; Sarker et al., 2017). When contrasting this concept with soft power it becomes obvious that soft power focuses on the former two observable forms, while hard power mainly concerns coercion. In addition, the actorcentred power concept is better capable of capturing very detailed, issue-specific power capabilities, which grand theories are likely to miss out on.

The use of power by the egoist state to secure its self-interest in an international system is supported by the neorealist paradigm (Kamminga, 2010) thus, it is interesting to understand what power strategies a state adopts while pursuing its interest when the issue is not related to national security per se but to the global issue of climate change.

As highlighted previously, climate change politics provides an immense scope for states to use 'soft power' strategies to position themselves to structure this debate.

2 The UNFCCC Conference of parties held in Copenhagen in 2009 
India, like other major global powers, has focused on the soft power approach lately (Lee, 2010; Purushothanam, 2010) and its foreign policy emphasises inter-governmental co-operation, negotiated settlements and economic collaboration (Wagner, 2010). India has been a defensive soft power (Wagner, 2005; Das, 2013), i.e., not using soft power to exert influence but mainly to build its image. In the context of REDD, however, India aimed to include incentives for conservation \& for the enhancement of carbon stocks and effectively used 'soft power' to mobilise the support of other countries in its demand to be accepted at the negotiation table.

\section{Methodological approach}

The research inquiry for this paper has been addressed using a qualitative research design. The qualitative analysis focused primarily on India's pro-active and strategic behaviour in the development of REDD discourse. It combines the methods of document analysis with supplementary expert interviews. Document analysis is a qualitative research technique. It allows the researcher to systematically evaluate the printed and electronic material and interpret the meaning around the text relevant to the topic of research (Bowen, 2009).

For carrying out the document analysis, the text documents, which were deemed most relevant to our research objective were identified and selected. Although India has prepared many documents (reports, policy briefs, comment-based reports, etc) for directly communicating with the UNFCCC through structured meetings of Subsidiary Body for Scientific and Technical Advice (SBSTA) ${ }^{3}$, our analysis focused on reports which were directly relating to REDD policy or documents that substantially reflect and disseminate India's stance on the REDD issue. The main documents that were included in the analysis are summarized in Table 1.

Table 1: Categories of documents analysed in the paper. In brackets: Number of documents considered in the analysis. For details see Annex 1.

\begin{tabular}{|c|c|c|c|}
\hline Source & Document type & Communicated with & Focus on \\
\hline $\operatorname{MoEF}(8)$ & $\begin{array}{l}\text { Statement/views report } \\
\text { (2) }\end{array}$ & $\begin{array}{l}\text { UNFCCC, SBSTA and AWG- } \\
\text { LCA (4) }\end{array}$ & $\begin{array}{l}\text { Defending REDD+ as } \\
\text { opposed to REDD (5) }\end{array}$ \\
\hline \multirow[t]{4}{*}{$\begin{array}{l}\text { Indian Council } \\
\text { of Forestry } \\
\text { Research and } \\
\text { Education } \\
\text { ICFRE (2) }\end{array}$} & Technical report (2) & Media (2) & $\begin{array}{l}\text { Highlighting India's stand on } \\
\text { the REDD debate (6) }\end{array}$ \\
\hline & $\begin{array}{l}\text { Official submission to the } \\
\text { UNFCCC (1) }\end{array}$ & Indian parliament (1) & $\begin{array}{l}\text { Promoting India's pro- } \\
\text { conservation approach in } \\
\text { forest management ( } 2 \text { ) }\end{array}$ \\
\hline & Others (5) & $\begin{array}{l}\text { International meeting } \\
\text { (1) }\end{array}$ & REDD+ financing (2) \\
\hline & & $\begin{array}{l}\text { National communication } \\
\text { (2) }\end{array}$ & $\begin{array}{l}\text { Reiterating India's interest in } \\
\text { REDD+ (7) }\end{array}$ \\
\hline
\end{tabular}

The numbers within brackets reveal the number of documents analysed under each category. A total of 10 documents (see Annex 1 ) were selected for the analysis. The numbers in the fourth column of the above table are overlapping based on the prominent focus of the document.

For triangulating the data, we conducted key informant interviews. Our key informants were the two experts: one was intensively involved at the domestic level with the Indian government's Ministry of Environment and Forests (MoEF) at the intersection of global and domestic REDD+ discourses in India. Another key informant is a World Bank's senior negotiator of global carbon issues, closely linked to REDD+ policymaking at the international level. Interviews and subsequent personal correspondence with the two experts provided first-hand information on India's stance in

\footnotetext{
3 The SBSTA counsels the Conference of the Parties (COP) on matters of climate change related policy issues and technical discussions on suitable methods) or other international meetings on emission trading/climate change (Michaelowa and Michaelowa, 2011)
} 
REDD politics from a domestic and an international perspective and helped validate data from the document analysis.

Table 2: Operationalizing the study from codes to themes in document analysis.

\begin{tabular}{|c|c|c|c|}
\hline & Codes generated & Main issues discussed & Themes identified \\
\hline 1 & Pro-Conservation policy approach & Scope of afforestation and & \multirow{4}{*}{$\begin{array}{l}\text { India proposed REDD+ } \\
\text { mechanism }\end{array}$} \\
\hline 2 & $\begin{array}{l}\text { Holistic/comprehensive approach to } \\
\text { REDD }\end{array}$ & $\begin{array}{l}\text { reforestation (A\&R) activities in } \\
\text { climate change mitigation; }\end{array}$ & \\
\hline 3 & REDDplus & Increase in forest cover; & \\
\hline 4 & $\begin{array}{l}\text { Opportunity cost of increased forest } \\
\text { cover }\end{array}$ & $\begin{array}{l}\text { Compensation/incentive to increase } \\
\text { forest cover }\end{array}$ & \\
\hline 5 & Compensated conservation & REDD funds for sustainable & \multirow{3}{*}{$\begin{array}{l}\text { India discarded REDD that } \\
\text { only focused on } \\
\text { deforestation and forest } \\
\text { degradation. }\end{array}$} \\
\hline 6 & Operationalisation of REDDplus & management of forests & \\
\hline 7 & $\begin{array}{l}\text { Unit of Carbon saved=Unit of carbon } \\
\text { added }\end{array}$ & $\begin{array}{l}\text { Monetary benefit for the conservation } \\
\text { of forest and carbon stock }\end{array}$ & \\
\hline 8 & $\begin{array}{l}\text { India in COPs (Bali to Cancun) and } \\
\text { other international meetings related } \\
\text { to REDD }\end{array}$ & $\begin{array}{l}\text { Promotion of REDD-Plus } \\
\text { Seeking alliance } \\
\text { Improving its international visibility }\end{array}$ & \multirow[t]{2}{*}{$\begin{array}{l}\text { India advancing its own } \\
\text { interest by emphasising the } \\
\text { "plus" in REDD. }\end{array}$} \\
\hline 9 & $\begin{array}{l}\text { India's written submission to the } \\
\text { UNFCCC }\end{array}$ & & \\
\hline 10 & $\begin{array}{l}\text { C-sequestration from India's forests } \\
\text { and tree cover }\end{array}$ & \multirow{4}{*}{$\begin{array}{l}\text { Promotion of self-image as pro- } \\
\text { conservation and proactive in forests } \\
\text { and climate change issue. }\end{array}$} & \multirow{9}{*}{$\begin{array}{l}\text { India used its soft power to } \\
\text { pursue the REDD-Plus } \\
\text { proposal on formal policy } \\
\text { agreement on REDD. }\end{array}$} \\
\hline 11 & Diversity of ecosystems in India & & \\
\hline 12 & Statistics on India's forest cover & & \\
\hline 14 & India hosting CBD COP-2012 & & \\
\hline 15 & Green India Mission & India's new domestic and international & \\
\hline 16 & REDDplus partnership & $\begin{array}{l}\text { initiatives related to forests and } \\
\text { climate change }\end{array}$ & \\
\hline 17 & $\begin{array}{l}\text { New terms like Sustainable } \\
\text { management of forests (SMF), } \\
\text { compensated conservation, etc. }\end{array}$ & $\begin{array}{l}\text { Initiation of new technical terms } \\
\text { gained support for India from forestry } \\
\text { networks such as UNEP, UN-FAO, etc. } \\
\text { and facilitated India's proposal at the } \\
\text { negotiation table. }\end{array}$ & \\
\hline \multirow[b]{2}{*}{18} & \multirow[b]{2}{*}{ The "Plus" in the REDD-Plus proposal } & $\begin{array}{l}\text { Structural circulation of REDD-Plus } \\
\text { proposal through political discourses } \\
\text { aligned to its allies (e.g., China) and } \\
\text { friendly international organisations } \\
\text { (UNFCCC, UN-FAO, UNEP etc). }\end{array}$ & \\
\hline & & $\begin{array}{l}\text { Structural circulation means that India } \\
\text { proposed its idea of 'compensated } \\
\text { conservation' in context of REDD to } \\
\text { incorporate the "plus" component in } \\
\text { REDD at various meetings and at } \\
\text { various levels. }\end{array}$ & \\
\hline
\end{tabular}

The iterative process of analysing documents involved two steps. First, the information generated by the documents was organized into categories related to the main line of research inquiry. The second step was to conduct thematic analysis. As the name suggests, thematic analysis involves identification of themes by carefully re-reading and reviewing the data (Rice \& Ezzy, 1999), and recognizing the pattern across the data, followed by a 'comprehensive process of data coding' (Fereday \& Muir-Cochrane, 2006:4). Fundamentally, thematic analysis establishes an analytical foundation to understand an issue on any social or political dimension and interpret it by exploring the salience of important themes in a text (Attride-Stirling, 2001). 
Figure 1: Basic, organizing and global themes emerging through thematic analysis.

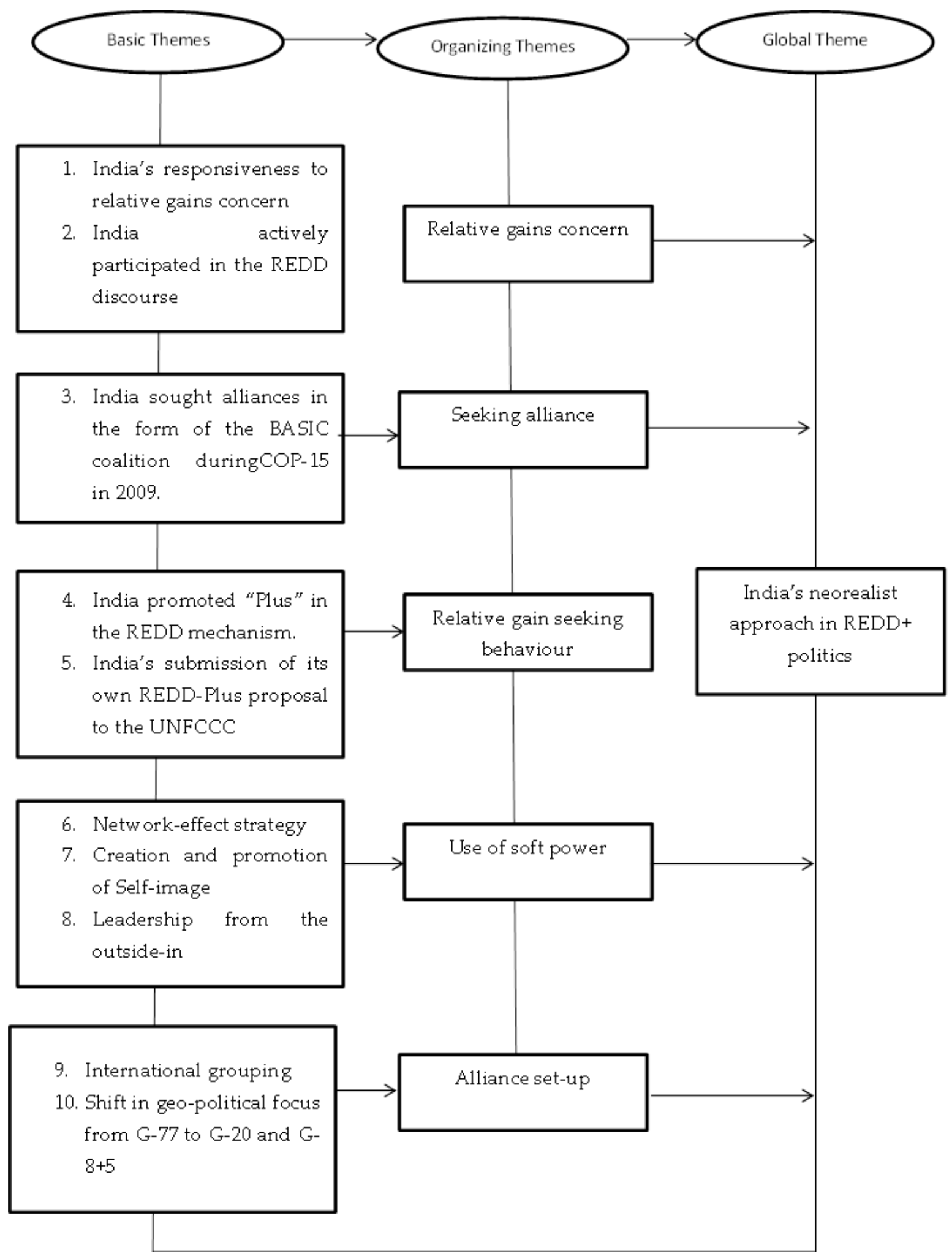

The key informant interviews were transcribed, followed by the identification of the most relevant text segments from the selected documents for this study (see Annexure 1). After the careful reading of the text data, broad items of interest were identified based on the core assumptions of the paper, for example, India's intervention in the REDD discourse, India's stance on the proposed REDD mechanism since 2005 till 2010 and if and how it has changed subsequently etc. 
The next step involved establishing the coding system. A total of 18 codes (see Table 2) were derived based on the:

a) Recurrent issues appeared in the data regarding the REDD and REDD+ mechanisms;

b) Recurrent issues appeared in the data regarding India vis-à-vis the REDD+ mechanism;

c) Specific theoretical interests regarding the means and strategies employed by India to pursue its interests in the REDD discourse.

Table 3: Definition of basic themes (as a part of the thematic analysis process)

\begin{tabular}{|c|c|}
\hline Basic Themes & Definition / contextual meaning \\
\hline $\begin{array}{l}\text { India's responsiveness to relative } \\
\text { gains concern }\end{array}$ & $\begin{array}{l}\text { India made sure to convey its point of view to the global climate } \\
\text { change community and all the parties to the UNFCCC by reiterating its }\end{array}$ \\
\hline $\begin{array}{l}\text { India actively participated in the } \\
\text { REDD discourse }\end{array}$ & $\begin{array}{l}\text { REDD alternative proposal called 'compensated conservation'. } \\
\text { Indian delegates participated in every meeting of the UN and others } \\
\text { with one frame of mind to propagate India's moral arguments asking } \\
\text { for financial rewards to countries that have increased forest cover and } \\
\text { thus carbon stocks in the past. }\end{array}$ \\
\hline $\begin{array}{l}\text { India sought alliances in the form } \\
\text { of BASIC coalition during COP-15 }\end{array}$ & $\begin{array}{l}\text { In Copenhagen, a newly formed group of advanced developing } \\
\text { countries (Brazil, South Africa, India and China: BASIC) emerged, and } \\
\text { India is said to have played a pivotal role in its formation. }\end{array}$ \\
\hline
\end{tabular}
in 2009.

India promoted "Plus" in the REDD

India's continuous submissions on REDD, reiterating the same mechanism. argument of compensated conservation, to the UNFCCC since COP 11 in 2005

India's submission of its own REDD-Plus proposal to the UNFCCC

Network-effect strategy

Creation and promotion of Selfimage

Leadership from the outside-in

International grouping

Shift in geo-political focus from G77 to $\mathrm{G}-20$ and G-8plus5
One of the most important submissions by India on REDD that was welcomed by the UNFCCC at COP-13 in Bali. The official decision of COP 13 for the first time included in the REDD negotiation text ' ... the role of conservation, sustainable management of forests and enhancement of forest carbon stocks in developing countries' India used its network not only with the other countries but also with inter-governmental bodies such as UNEP and FAO to market its rather innovative and win-win approach for the REDD mechanism.

India has promoted its pro-conservation approach and willingness to curb emissions in all its domestic and international communications very well, where it claimed to increase its forest cover in the recent past and had adopted pro-conservation strategies and policies at the domestic level to engage in afforestation and reforestation activities. India took over the discussion from its counterparts, for example Brazil and China, on issues related to REDD. Additionally, it effectively circulated its own agenda on REDD among the other parties to the UNFCCC.

Currently, India is seen to be actively engaged in strategic partnerships with large economies such as the US and EU, along with China, Brazil and South Africa in bilateral and trilateral partnerships.

India has always been a significant partner in the G-77; however, it has now shown a very clear intention to align its interests with a smaller but powerful group of countries.

These three foci were then combined, and, by reading through the text segments, the most salient constructs in the documents were identified and refined into a finite set of discrete and meaningful codes. The coding eased and clarified the recognition of relevant pieces of information and simplified the filtering and reduction of the data for further analysis. In Table 2, we show the main elements identified in the REDD+ documents consulted in the research, which were further combined to identify broad themes in context of India vis-à-vis REDD+. 
Once Table 2 was created, the text segments in the data were revisited to further identify 'basic themes'. These basic themes were generally identified as the first order of patterned response or meaning within the data set in relation to the research hypotheses (Braun and Clarke, 2006).

At this stage, each basic theme was given a concise definition, which are described in Table 3. The basic themes were then trawled back to data (texts) and were defined and contextualised, hence the construction of each basic theme is checked and re-checked for explanatory power.

Further, by carefully examining the texts, the basic themes were grouped into clusters of categories to summarise the overall meanings. They are called 'organising themes'. Finally, the super-ordinate theme that fairly encapsulated the principal rhetoric in the texts emerged as the 'global theme' (Attride-Stirling, 2001). Figure 1 shows the prominent basic themes identified in the analysis of the REDD documents consulted in the research, which were further combined to identify the organising themes in context of India vis-à-vis REDD+ and then were further amalgamated to the broad global theme, in keeping with the core assumptions of this paper.

\section{Findings and Discussion}

\subsection{India's interest in the "Plus" of REDD}

Figure 2: The history of REDDplus negotiations (adapted from Holloway and Giandomenico, 2009: 4).

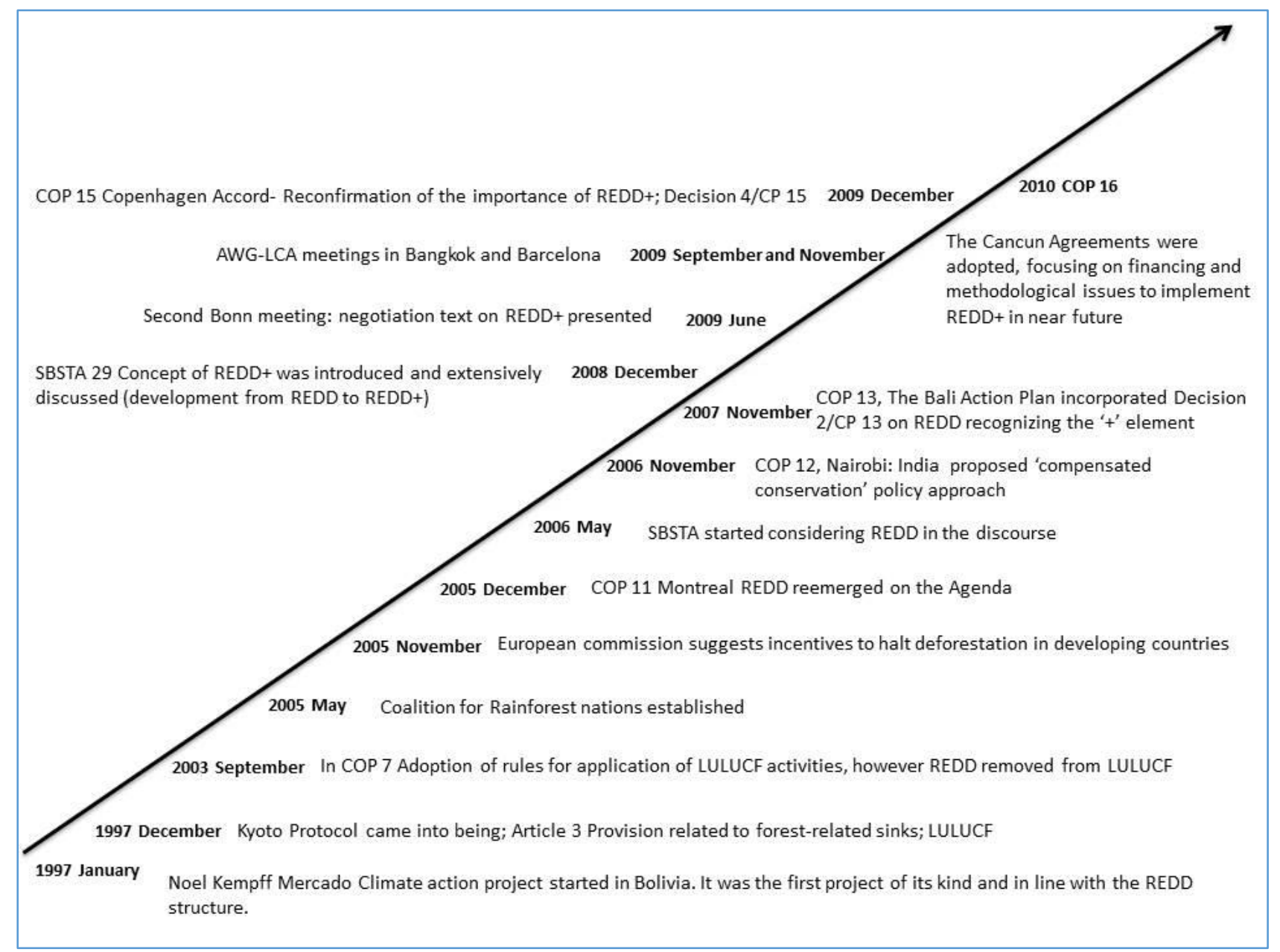

Official documents generated by the MoEF on issues related to the forest's role in climate change mitigation clearly reflect India's support for financial incentives such as REDD and the clean development mechanism (Gundimeda, 2004). In the context of REDD, India seemed to have maintained a clear position on compensating countries for the carbon sequestration provided by 
their forest cover. At COP 12, 2006 in Nairobi, India proposed "compensated conservation" as a new policy approach in REDD discourse, providing a new perspective and momentum to the REDD negotiation in the international arena (MoEF, 2010). India continued to emphasize on compensated conservation policy in the context of reducing emissions from deforestation in developing countries during the second UNFCCC SBSTA workshop in Cairns in 2007 (Kishwan, 2007). This new policy approach puts emphasis on compensating the countries for maintaining and increasing carbon pools of their forests as a result of conservation and increase/improvement in forest cover backed by a verifiable monitoring system. During all the negotiations happening at an international level (see Figure 2), India never opposed the REDD concept. However, from time to time it continued to emphasize that reduction of deforestation and the enhancement of forest carbon stocks are two sides of the same coin (MoEF, 2010), thus should be treated equally whenever the mechanism is operationalized in the future.

India advocated for compensated conservation approach by using the argument of justice and equity. The emphasis was made on rewarding countries that have taken strong steps in the past to halt deforestation and promote forest conservation (Pant, 2009). Following is an excerpt from one of the documents that highlights India's quest to seek compensation for conservation. (excerpt from "views of India to UNFCCC on REDD", 3):

"Protection and sustainable management of forests need to be considered as positive practices to avoid deforestation. Nations with continued deforestation and now committing to reduce deforestation rates, and those having already taken up strong conservation measures and thereby stabilizing and increasing the forest cover ... present a fit case to be rewarded under REDD, as these efforts reduce the emission of carbon in atmosphere/capture atmospheric carbon, in the process.

In the REDD discourse, some concerns were floating that the distribution of benefits may be unequal among the participating countries ${ }^{5}$ depending on the choice of scope, reference level, distribution, and funding mechanism of a given proposal (Parker et al., 2008). Da Fonseca et al. (2007) claimed that countries with historically high deforestation rates will gain more from REDD, for example, Brazil and Indonesia. Table 4 shows four categories of developing countries developed by Da Fonseca et al. (2007) based on countries forest cover and deforestation rates.

Table 4. Matrix of countries by their levels of forest cover and historical rates of deforestation, adapted after Da Fonseca et al. (2007).

\begin{tabular}{|c|c|c|}
\hline & Low Forest Cover (< $50 \%)$ & High Forest Cover (> 50\%) \\
\hline $\begin{array}{l}\text { High } \\
\text { Deforestation } \\
\text { Rate } \\
(>0.22 \% / y r)\end{array}$ & $\begin{array}{l}\text { Quadrant I } \\
\text { E.g., Madagascar, Thailand } \\
\text { High potential for benefits from reducing } \\
\text { emissions from deforestation } \\
\text { High potential for benefits from } \\
\text { reforestation activities and CDM }\end{array}$ & $\begin{array}{l}\text { Quadrant III } \\
\text { E.g., Brazil, Indonesia } \\
\text { High potential for benefits from } \\
\text { reducing emissions from deforestation } \\
\text { Low potential for benefits from } \\
\text { reforestation activities and CDM }\end{array}$ \\
\hline $\begin{array}{l}\text { Low } \\
\text { Deforestation } \\
\text { Rate } \\
(<0.22 \% / y r)\end{array}$ & $\begin{array}{l}\text { Quadrant II } \\
\text { E.g., India, China, South Africa } \\
\text { Low potential for benefits from reducing } \\
\text { emissions from deforestation } \\
\text { High potential for benefits from } \\
\text { reforestation activities and CDM }\end{array}$ & $\begin{array}{l}\text { Quadrant IV } \\
\text { E.g., Suriname Gabon } \\
\text { Low potential for benefits from reducing } \\
\text { emissions from deforestation } \\
\text { Low potential for benefits from } \\
\text { reforestation activities and CDM }\end{array}$ \\
\hline
\end{tabular}

\footnotetext{
${ }^{4}$ It is a policy approach proposed by India which provides financial incentives to the countries for maintaining and increasing their forests as a result of conservation.

${ }^{5}$ Participating countries here refer to all those developing countries that will host REDD+ activities as part of the climate change mitigation policy
} 
As India's deforestation rate has been stabilised over the time, and forest cover increased by 4.75\% on net from 1997 to 2007 (MoEF, 2009), it becomes clear that REDD policy did not sufficiently cater to India's interests unless forest conservation and enhancement activities are included in the scope of the mechanism (Paul and Chakrabarti, 2011; Basu and Nayak, 2011). India proactively argued that the high opportunity cost associated with the stabilisation, maintenance and conservation of forest cover must also be recognised (Potvin and Bovarnik, 2008; MoEF, 2009). In one of the interviews, an Indian expert mentioned that:

"REDD+ may not be that lucrative for India in terms of money but has immense capacity to mitigate climate change along with bringing multiple co-benefits. Maybe India sees REDD+ as an opportunity to get external and additional funding for performing its national climate change mitigation tasks such as Green India Mission."

A study conducted by Pant (2009), used a SWOT (Strength Weakness Opportunities and Threat) analysis technique along with quantitative trend analysis of forest degradation to assess the potential for REDD in India. The study concludes that the "success of REDD+ in India lies primarily in the "plus" component, i.e., projects based on conservation and enhancement of carbon stocks and reducing emissions from degradation in specific regions."

Our analysis based on the key interviews and the available literature ${ }^{6}$ on India vis-à-vis REDD policy conform with the previous studies, where India showed interest in REDD discourse primarily to pursue the "Plus" component within REDD. The next section explains India's interest in REDD+ as seen from the relative gains perspective.

\subsection{India's responsiveness to relative gains concerns}

From 1995 until 2010, India faced three alternatives ${ }^{7}$, which it could primarily pursue while participating in the REDD policy discourse:

1) India could accept REDD as it was initially formulated i.e., focused solely on deforestation and forest degradation.

2) Abandon REDD altogether and not participate in the REDD discourse.

3) Use soft power strategies to remodel REDD and include the "plus" component, i.e., the conservation and enhancement of carbon stock and the sustainable management of forests.

Of the three options, the third was the most beneficial; the first option could have been a last resort, whereas the second could have brought loss in absolute terms. For India to have taken the first option and accepted REDD unconditionally as outlined in COP 13 would have reflected an insensitivity to relative gain concerns. However, by taking the third option, i.e., rejecting the initial REDD mechanism and reconfiguring it to include the "plus" component, India clearly demonstrated a keen sensitivity to relative gain concerns, i.e., to the fear that REDD would disproportionately benefit other developing countries, which could possibly become detriment to the Indian "emerging global power" projection.

\footnotetext{
6 The documents analyzed for this purpose, accessed between September 2010 to March, 2011, were mainly from the Ministry of Environment and Forests, Government of India, http://moef.nic.in ; COP 13 agreement of the UNFCCC, FCCC/CP/2007/6/Add.2; COP 15 agreement of the UNFCCC, unfccc.int/resource/docs/2009/cop15/eng/l07.pdf; COP 16 agreement of the UNFCCC, unfccc.int/files/meetings/cop_16/application/pdf/cop16_Ica.pdf; India's submission to the UNFCCC on longterm co-operative actions, unfccc.int/files/kyoto_protocol/application/pdf/indiasharedvisionv2.pdf; India's REDD+ submission to the UNFCCC, moef.nic.in/downloads/home/UNFCCC-final.pdf

7 This section is drawn from Mastanduno, 1991, in which the America's response to Japanese industrial policy is studied keeping the 'relative gains concern' in consideration, see Michael Mastanduno, "Do relative gains matter? America's response to Japanese industrial policy," International Security, Vol. 16, No.1 (1991), pp. $73-113$
} 
India's preference for the third option also clearly reflects India's relative gain seeking behaviour. Instead of limiting REDD benefits to other countries, India sought to co-operate with a focus on absolute gains. Hence India consciously sought to change the REDD mechanism to maximise the benefits in its own favour (see Table 3 and 4). By convincing the global community to accept the "plus" component, India opened the possibility for harnessing the financial benefits of the REDD+ mechanism.

In this context and in light of the realist argument put forth earlier, we argue that India exhibited relative gain-seeking behaviour, took advantage of any opportunity to emerge as a major player in the REDD negotiations and, to a great extent, failed the attempts of other rising powers, such as Brazil, to dominate the REDD discourse at the global level.

\subsection{India's use of 'soft power' to remodel REDD to REDD+}

By advocating for 'compensated conservation' approach, India used ethics-based (equity and justice) negotiation tactics throughout the REDD discourse. India strategically participated in all the technical and methodological workshops (SBSTAs of the UNFCCC) and related meetings worldwide to form various negotiating blocs/coalitions and succeeded in gradually developing consensus around the idea of a "plus" component and having that component included in the REDD agreement at COP-16, in 2010.

In this section, we discuss how India adopted the soft power strategy to promote its 'compensated conservation' proposal with regard to the inclusion of forests in mitigating the global emissions. The idea of compensated conservation eventually became reality in the current REDDPlus mechanism. Figure 3 shows the network of themes emerged in the analysis. In our analysis we found that there were some key soft power strategies that were used by India to pursue its interest. They are discussed as below:

1) Self Image promotion: In all the major documents generated by the Indian MoEF ${ }^{8}$, on REDD and related issues, it is evident that India projected its domestic policies as being pro-conservation. India boasted about its increase in forest cover over the 1995-2005 period. India also highlighted its commitment to community participation in forest management (such as the Joint Forest Management mechanism widely spread and functional across the nation (see e.g. Paul and Chakrabarti, 2011; Misra and Kant, 2004; Behera and Engel, 2006). The example of 'self-image promotion' evident in several documents is: "Over the past decades, national policies of India aimed at conservation and sustainable management of forests have transformed India's forests into a net sink of $\mathrm{CO} 2$ (Box 1 No.10, Kishwan et al.2009)

2) Leadership from the outside-in: In the context of this paper, this strategy relates to the "indirect exertion of soft power" through the structural circulation of India's REDD+ proposal at political discussions (e.g., SBSTA meetings) aligned with its ally countries (Chong, 2007:7).

3) Network-effect strategy: This strategy pertains to India's quest to establish networks on the basis of a common reference point (Lee, 2009), i.e., REDD is skewed in favour of high forest high deforestation (HFHD) countries. This strategy helped to create an external environment favourable to India's 'compensated conservation' proposal. Additionally, the inclusion of new technical terms in the REDD discourse, such as replacing the concept of sustainable management of forests with sustainable forest management, gained support for India from forestry networks surrounding e.g. UN-FAO ${ }^{9}$ and smoothed the reception of India's proposal at the negotiation table (see Table 3).

4) Alliance: India's global effort to make alliances in the form of "international groupings" is notable, and the most relevant of these groupings in the climate change arena was the BASIC (Brazil, South Africa India and China) bloc. It played prominent role during COP 15 in Copenhagen. The main agenda of BASIC coalition was to put off the pressures from the United States of America

\footnotetext{
8 These documents are the official statements, presentations, briefs, working papers etc on India's stand and viewpoint on REDD and REDD+ published on behalf of the Ministry of Environment and Forests, Government of India. http://moef.nic.in

${ }_{9}^{9}$ United Nations Food and Agriculture Organization
} 
to commit to fixed emission reduction targets and deciding on the peaking year of the emissions. The other strategic partnerships also exist, such as BRIC, Brazil-India (Skak, 2011), Brazil-India-South Africa trilateralism (Stuenkel, 2010), etc. These engagements of India in strong multilateral groupings indicate not only its soft power approach (Alden and Vieira, 2005) but also its shift in diplomatic focus from the G-77 to the G-20 and the G-8plus5; this shift further explains the proactive behaviour of India in climate change politics. Since 2010, India has constantly worked to change its image from a climate laggard to a climate leader (Rastogi, 2011) and India has borne the fruit of such efforts in the form of strong support from the USA and Russia for India's candidacy for a permanent seat on the Security Council (Skak, 2011).

Figure 3: Network of emerging key themes

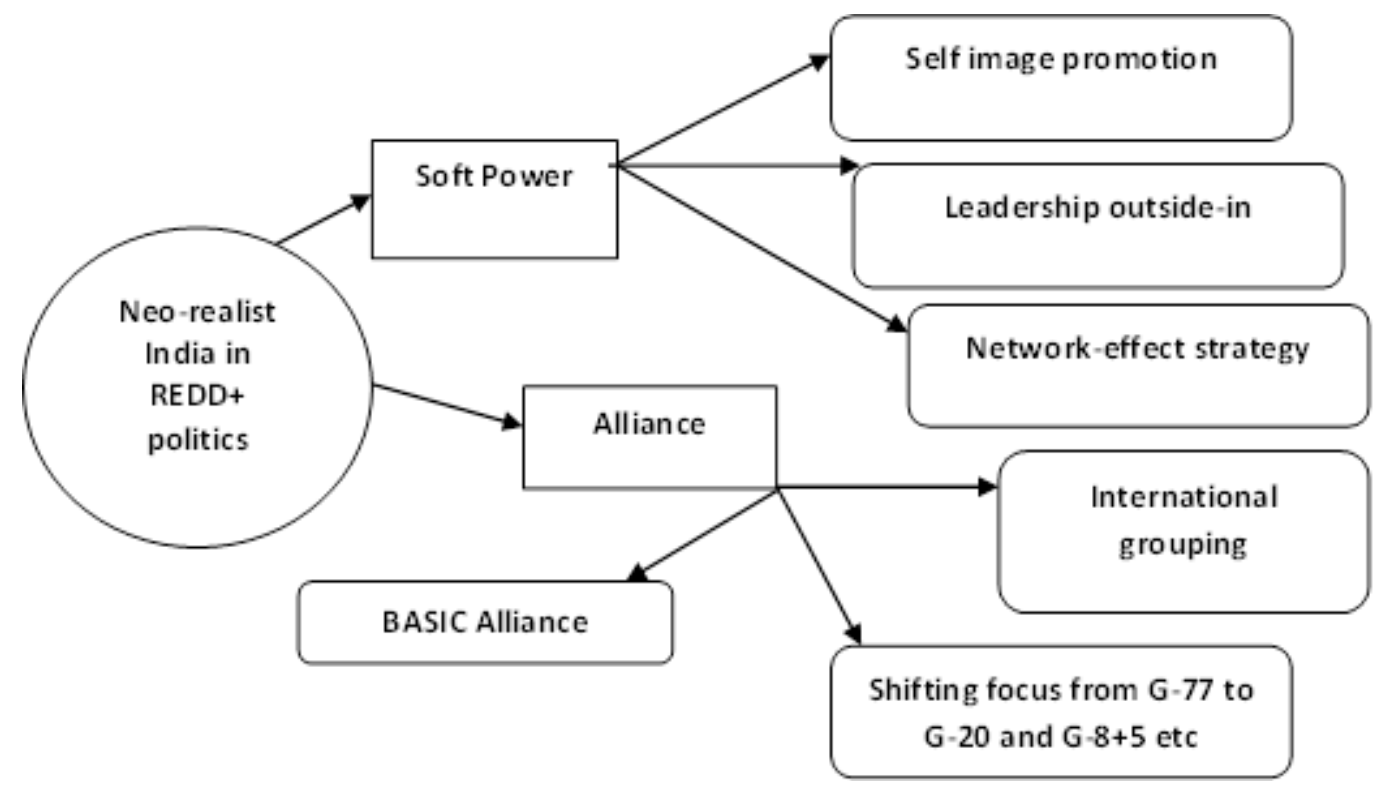

Our analysis provides good insight on why and how India played a significant role in REDD negotiations. However, we must be cautious in drawing conclusions without recognizing the limitations of this study. Firstly, the amount of data limits the scope of our study. More key informant interviews, especially during an on-going REDD event could have allowed for more robust and comparative analysis. But due to time constraint we rely only on two key informants along with document analysis. Secondly, as many of documents used for this research are published by the MoEF, Government of India for the international audience, it limits the scope for understanding any hidden interest in REDD + for example interest in REDD+ may be motivated by the opportunity to increase recentralization of forest management. Thirdly, we should make a note that the consensus on adding the "plus" in REDD mechanism could have been facilitated by the global community to avoid "international leakage" associated with the REDD mechanism. International leakage may occur when reduction of emissions in one country (due to the REDD+ implementation) may lead to an increase in emissions in another country. In other words, leakage is simply an emission displacement and to avoid such leakage, participation of as many countries possible is required to implement the REDD+ policy and projects simultaneously. Thus including a broad scope of activities in The REDD mechanism allows for the maximum number of developing countries to operate within the REDD mechanism. Nevertheless, the role of India to push for the 'plus' in the REDD agenda cannot be underestimated.

Based on the findings of our paper, we argue that India played a proactive role in putting across its specific interest in REDD mechanism. Our findings are although specific to its role in REDD negotiations, they strongly conform to the studies focused on India's broad role in global climate politics. India has used equity-based arguments to put strong emphasis on 'common but differentiated responsibilities (CBDR)' (Rajan, 1997; Barua, 2017), which means that developing and developed countries should have different levels of obligations and responsibilities to reducing 
greenhouse gas emissions. In the literature, it is evident that India sought an important role for itself in global climate negotiations (Jakobsen, 1999; Sengupta, 2012; Dröge \& Wagner, 2015).

\section{Conclusion}

The literature on global environmental politics is influenced largely by the neoliberal institutionalist literature (Elliot, 1998; Stripple, 2006;). The literature however also indicates the use of regime theory (see Hasenclever et al., 1996), constructivist theory (see Haas, 1992; Litfin, 1994; Paterson, 2006) and realism (Bulkeley and Newell, 2010) to understand global politics around pressing environmental issues. In the literature, especially pertaining to climate change politics, the use of interest-based theories have been widely used to explore the role of countries in pursuing climate change discourse and joining international agreements (Purdon, 2014). However, most studies focus on the economic aspect of climate diplomacy and assume that the countries are motivated to cooperate in international agreement countries because of the absolute gains to make them better off than the other countries (Ike, 2016). In this paper we, however argued that power is a relative concept (Dahl, 1969) and so the concern over relative gains to preserve the pre-existing balance of power along with absolute gains steers the international agreements related to climate change (Grieco, 1988). Countries that are in the leadership race, aiming for the underlying goal of enhancing their regional and/or global power in an international system have a lot at stake in the politics of global climate change (Motaal, 2010). However, unlike national security, the stakes in the climate change discourse are not high enough to warrant the use of hard power within realism. Hence, the concepts of high and low politics (Willets, 2001) are too narrow for this empirical application. The case of climate change politics suggests that the concepts should be widened into a continuum from low politics to high politics to high security politics.

In essence our study suggests that strong states, such as BRICS, at ease seem to be capable of joining an on going international regime and its policy deliberations, to which they had not been members or addressees in a first place. In addition, such strong emerging states, in case they attain sufficient issue-related (soft) power, are even capable of substantially remodelling a strongly evolving policy paradigm, such as REDD, into a quite different approach more in line with their interests. It remains unclear, however, if the Indian intervention alone is a sufficient explanation, or if similar interventions by e.g. China had been necessary to provide the issue-specific power required for the remodelling from REDD to REDD+. The observed appropriation of international processes and policies in the pursuit of political self-interests has in the literature been termed "customization" of international regimes (Thomann, 2015; Giessen, forthcoming, Logmani et al., 2017). The processes through which such customizations are achieved, however, will need more in-depth scrutiny in the future.

In our paper, we analysed how India played a major role in expanding the REDD global climate change mitigation policy to REDD+. India pursued its national interest in gaining benefits from REDD along with its (latent) goal of establishing itself as one of the significant leaders in climate politics. This reflects India's realist outlook in the international system. India showed its concern for the relative gains associated with REDD and actively participated in the discourse from SBSTA 24 (2006) to the present. India's agenda on the international stage has been clear, and India has reiterated its demand for the treatment of 'plus' at par with deforestation and forest degradation. Recent studies claim that India used hard and soft strategies such as proposing new solutions in the common interest, along with "strong morally loaded arguments on fairness and responsibility, and high opening demands on industrialised countries carrying all the cost are typical characteristics of India's traditional defensive, distributive strategy, while obviously being in India's self-interest." (Michaelowa and Michaelowa, 2011: 6).

Our findings suggest that India was not only responsive to relative gains concerns but also exhibited clear relative gain-seeking behaviour. India initiated its participation in REDD discourse because of its concern over losing potential REDD funds to other developing countries. Nevertheless, India embarked on the opportunity by proposing a rather new approach of 'compensated conservation', which translated to the REDD+ policy, hence remodelling it from its earlier structure. 
This has provided India with two main benefits: potential REDD funds and the enhancement of its image as a powerful actor in climate politics.

Additionally, India sought an alliance in the form of the BASIC bloc, which not only gave a common platform to resolve contentious REDD issues with Brazil but also provided one to advance its climate agenda with the support of other emerging economies. This coalition highlights the soft balancing strategy of the major economies in climate negotiations. Here, soft balancing strategy refers to forming the alliance with other major economies for putting away the pressure from the USA to commit to the emission reduction targets, without any major confrontation.

India's leading effort to include the "plus" component in the REDD agenda was successful at COP 16 in Cancun in 2010 and the UNFCCC parties acceded to the REDD+ agreement (see Cancun agreement on REDD+; FCCC/CP/2010/7/Add.1). This shows how India utilised soft power strategies in the process of pursuing its interests without having any major confrontations with the global community.

For the purpose of this paper, we utilized the neo-realist concept of relative gains along with the theoretical concept of soft power. It provided a good point of departure for examining India's role in climate change politics. However, the scope of this paper is limited to examine only a small segment of India's role in 'forest and climate change discourse' within the overall climate governance. We believe, further research is required to undertake on India's role in other sectors of climate change mitigation and adaptation to gain deeper perspective on India's role in climate governance, which is although pacing up yet not fully realised.

\section{Acknowledgement}

The authors gratefully acknowledge the expert interviewees. The authors would also like to thank Ms. Pallavi Pant for sharing her unpublished Master thesis and the anonymous reviewers for their critical, yet very helpful comments on previous drafts. Financial support by the German Research Foundation (DFG) is greatly acknowledged.

\section{References}

Alden, C. and Vieira, M.A. (2005). The new Diplomacy of the South: South Africa, Brazil, India and Trilaterlism. Third World Quarterly, 26(7): 1077-1095.

Atteridge, A., M.K. Shrivastava, N. Pahuja, and H. Upadhyay. (2012). Climate Policy in India: What Shapes International, National and State Policy? Ambio, 41(1): 68-77. https://doi.org/10.1007/s13280-011-0242-5

Attride - Stirling, J. (2001). Thematic networks: an analytic tool for qualitative research. Qualitative Research, 1(3): 385-405.

Barua, M. (2017). India's Environmental Strategy in the Global Climate negotiations. International Studies, 51(1-4): 195-211.

Basu, A and Nayak, N.C. (2011). Underlying causes of forest cover change in Odisha. Forest Policy and Economics, 13(7): 563-569.

Behera, B and Engel, S. (2006). Institutional analysis of evolution of joint forest management in India: A new institutional economics approach. Forest Policy and Economics, 8(4): 350-362.

Bowen, G.A. (2009). Document Analysis as a Qualitative Research Method. Qualitative Research Journal, 9 (2): 27-40. https://doi.org/10.3316/QRJ0902027

Braun, V. and Clarke, V. (2006). Using thematic analysis in psychology. Qualitative Research in Psychology, 3:77-101.

Breslin, S. (2011). The soft notion of China's 'Soft Power'. Asia Programme Paper: ASP PP 2011/03. London: Chatham House.

Bulkeley, H. and Newell, P. (2010). Governing Climate Change. London: Routledge.

Chong, A . (2007). The Foreign Policy Potential of "Small State Soft Power" Information Strategies . Singapore: National University of Singapore.

Da Fonseca G.A.B, Rodriguez, C.M. Midgley, G. Busch, J. Hannah, L. Mittermeier, R.A. (2007). No Forest Left Behind. PLoS Biol, 5(8): e216. 
Dahl, R.A. (1969). The Concept of Power. In Political Power: A Reader in Theory and Research, edited by Roderick Bell, David V . Edwards, and R. Harrison Wagner, 79-93. New York: Free Press.

Das, A.K. (2013). Soft and Hard Power in India's Strategy Toward Southeast Asia. India Review, 12(3): 165-185.

Dröge, S., and Wagner. C. (2015). India's position in international climate negotiations: No shift under Modi (SWP Comments). Berlin: Stiftung Wissenschaft und Politik.

Elliott, L. (1998). The global politics of the environment. New York: New York University Press.

Fereday, J., and Muir-Cochrane, E. (2006). Demonstrating rigor using thematic analysis: A hybrid approach of inductive and deductive coding and theme development. International Journal of Qualitative Methods, 5(1): 1-11.

Giessen, L, Sahide, M.A.K. (2017): Blocking, attracting, imposing, and aligning: The utility of ASEAN forest and environmental regime policies for strong member states. In: Land Use Policy, 67, 13-26. http://www.sciencedirect.com/science/article/pii/S0264837716305002

Giessen, L. Sarker, P. K., Rahman, Md. S. (2016): International and Domestic Sustainable Forest Management Policies: Distributive effects on power among state agencies in Bangladesh. In: Sustainability, 8 (335), 1-28. http://www.mdpi.com/2071-1050/8/4/335/pdf

Giessen, L., Krott, M., Möllmann, T. (2014): Increasing representation of states by utilitarian as compared to environmental bureaucracies in international forest and forest-environmental policy negotiations. In: Forest Policy and Economics, 38 (2014), 97-104, http://dx.doi.org/10.1016/j.forpol.2013.08.008

Giessen, L. (2013): Reviewing the main characteristics of the international forest regime complex and partial explanations for its fragmentation. In: International Forestry Review, 15 (1), 6070. http://www.ingentaconnect.com/content/cfa/ifr/2013/00000015/00000001/art00005

Giessen, L. (forthcoming): Forests and the two faces of international governance: Customizing international regimes through domestic politics. Edward Elgar, Series on New Horizons in Environmental Politics (accepted).

Grieco, J.M. (1988). Anarchy and the limits of cooperation: A realist critique of the newest liberal Institutionalism. International Organization, 4(2): 485-507.

Gundimeda, H. (2004). How 'sustainable' is the 'sustainable development objective' of CDM in developing countries like India? Forest Policy and Economics, 6(3-4): 329-343.

Haas, P. (1992). Introduction: Epistemic communities and international policy coordination. International Organisation, 46(1), 1-35.

Hasenclever , A., P. Mayer and V. Rittberger. (1996). Interests, Power, Knowledge : The Study of International Regimes. Mershon International Studies Review, 40(2): 177-228.

Holloway, V. and E. Giandomenico. (2009). Carbon Planet White Paper: The History of REDD Carbon Policy, Adelaide: Carbon Planet Ltd.

Humphreys, D. (2006). Logjam - Deforestation and the crisis of global governance. Earthscan: London.

Humphreys, D. (2008).The politics of 'avoided deforestation': historical context and contemporary issues. International Forestry Review, 10 (3): 433-442.

Ike, V.C.O. (2016). Are Countries in Environmental Cooperation Concerned About Relative Gains? Master's Theses.192. The University of Southern Mississippi, USA. http://aquila.usm.edu/masters_theses/192

Jakobsen, S. (1999). International relations theory and the environment: A study of Brazilian and Indian policy-making on climate change. Copenhagen: University of Copenhagen, Institute of Political Science.

Jang J., McSparren J., Rashchupkina Y. (2016). Global governance: present and future.

Palgrave Communications, 2: 1-5. DOI: 10.1057/palcomms.2015.45

Kamminga, M, R. (2010). Is Neorealism Obsolete? Etzioni's Communitarian Confirmation of Neorealist Theory. Crossroads, 9(1): 5-39.

Karsenty, A., \& Ongolo, S. (2012). Can "fragile states" decide to reduce their deforestation? The inappropriate use of the theory of incentives with respect to the REDD mechanism. Forest policy and economics, 18, 38-45. 
Keohane, R.O. (1998). International institutions: can interdependence work? Foreign Policy, 110 : 82-96.

Kishwan, J. (2007). Reducing emission from deforestation in developing countries: Indian proposal. Paper presented at 2nd UNFCCC Workshop on REDD, Cairns, Australia, 7-9 March 2007. accessed on March 2011 http://unfccc.int/files/methods_and_science/lulucf/application/pdf/070307kishwan.pdf

Kishwan, J., Pandey, R., \& Dadhwal, V. K. (2009). India's Forest and Tree Cover: Contribution as a Carbon Sink (Technical Paper no. 130). Dehradun, India: Indian Council of Forestry Research and Education.

Krott, M., Bader, A., Schusser, C., Devkota, R., Maryudi, A., Giessen, L., \& Aurenhammer, H. (2014). Actor-centred power: The driving force in decentralised community based forest governance. Forest Policy and Economics, 49, 34-42.

Lee, G. (2009). A theory of soft power and Korea's soft power strategy. Korean Journal of Defense Analysis, 21(2): $205-218$.

Lee, J. (2010). Unrealised Potential: India's 'Soft Power' Ambition in Asia. Foreign policy analysis, 4: $1-18$

Litfin, K. (1994). Ozone discourses: Science and politics in global environmental cooperation. New York: Columbia University Press.

Lövbrand, E. (2009). Revisiting the politics of expertise in light of the Kyoto negotiations on land use change and forestry. Forest Policy and Economics, 11 (5-6): 404-412.

Logmani J., Krott M., Lecyk M., Giessen L (2017): Customizing elements of the International Forest Regime Complex in Poland? Non-implementation of a National Forest Programme and redefined transposition of NATURA 2000 in Bialowieza Forest. In: Forest Policy and Economics, 74, 81-90, http://dx.doi.org/10.1016/j.forpol.2016.11.004 .

Luttwak, E. N. (1990). From Geopolitics to Geo-Economics. The National Interest, 20:17-24.

Maryudi, A., \& Sahide, M. A. (2017). Research trend: power analyses in polycentric and multi-level forest governance. Forest Policy and Economics, 81, 65-68.

Mastanduno, M. (1991). Do relative gains matter? America's response to Japanese industrial policy. International Security, 16(1): 73-113.

Michaelowa, K and Michaelowa, A. (2011). India in the international climate negotiations: from traditional nay-sayer to dynamic broker. CIS working paper No. 70, Center for Comparative and International Studies (ETH Zurich and University of Zurich).

Misra, D and Kant, S. (2004). Production analysis of collaborative forest management using an example of joint forest management from Gujarat. Forest Policy and Economics, 6 (3-4): 301320.

Ministry of Environment and Forests (MoEF). (2009). Climate Change negotiations: India's submission to the United Nations framework Convention on Climate change. Government of India, August 2009. http://moef.nic.in/downloads/home/UNFCCC-final.pdf

Ministry of Environment and Forests (MoEF) (2010). Statement by Vijai Sharma, Secretary of the in Oslo Climate and Forest Conference, 27th May 2010. Accessed September, 2010 http://moef.nic.in/downloads/public-information/OSLO_Conference.pdf

Motaal, D, A. (2010). The Shift from 'Low Politics' to 'High Politics' - Climate Change. Environmental Policy and Law, 40 (2/3): 98-108.

Morgenthau, H.J. (1956). Politics Among Nations, New York: Alfred A. Knopf

Mosher, J.S .(2003). Relative Gains Concerns When the Number of States in the International System Increases. The Journal of Conflict Resolution, 47(5): 642-668.

Nijnik, M and L. Bizikova. (2008). Responding to the Kyoto Protocol through forestry: A comparison of opportunities for several countries in Europe . Forest Policy and Economics, 10(4): 257-269

Nye, J.S. (1990). Soft Power. Foreign Policy, 80: 153-171.

Nye, J.S. (2004a). Soft power: The means to success in world politics, New York: Public Affairs

Nye, J.S. (2004b). The decline of America's soft power. Foreign Affairs, 83(3): 16-20

Olivier, J. G. J., Janssens-Maenhout, G. Muntean, M. and Peters, J. A. H. W. (2016). Trends in global CO2 emissions: 2016 report. The Hague: PBL Netherlands Environmental Assessment Agency; Ispra: European Commission, Joint Research Centre. 
Pant, P. (2009). Reducing Emissions from Deforestation and Forest Degradation: An Assessment of Opportunities and Challenges in Indian Context. (Unpublished M.Sc Diss., TERI University, New Delhi).

Parker, C., Mitchell, A., Trivedi, M., \& Mardas, N. (2008). The Little REDD+ Book: A guide to governmental and non-governmental proposals from reducing deforestation and forest degradation. Oxford: Global canopy Programme.

Paterson, M. (2006). Theoretical perspectives on international environmental politics. In M. Betsill, K. Hochstetler, \& D. Stevis (Eds.), Palgrave advances in international environmental politics (pp. 54-81). New York: Palgrave Macmillan.

Paul, S and Chakrabarti, S. (2011). Socio-economic issues in forest management in India. Forest Policy and Economics, 13(1): 55-60.

Pistorius, T., H. Schaich, G. Winkel, T. Plieninger, C. Bieling, W. Konold, K.R. Volz. (2012). Lessons for REDD+: A comparative analysis of the German discourse on forest functions and the global ecosystem services debate. Forest Policy and Economics, 18: 4-12.

Potvin, C and Bovarnick, A. (2008). Reducing Emissions from Deforestation and Forest Degradation in Developing Countries: Key Actors, Negotiations and Actions. The Carbon \& Climate Law Review, 2, (3): 264-272.

Powell, R. (1991). Absolute and Relative Gains in International Relations Theory. The American Political Science Review, 85(4): 1303-1320.

Prabowo, D., Maryudi, A., \& Imron, M. A. (2016). Enhancing the application of Krott et al.'s (2014) Actor-Centred Power (ACP): The importance of understanding the effect of changes in polity for the measurement of power dynamics over time. Forest Policy and Economics, 62, 184-186.

Prabowo, D., Maryudi, A., \& Imron, M. A. (2017). Conversion of forests into oil palm plantations in West Kalimantan, Indonesia: Insights from actors' power and its dynamics. Forest Policy and Economics, 78, 32-39.

Purdon, M. (2014) .Neo-classical Realism and International Climate Change Politics: Moral Imperative and Political Constraint in International Climate Finance. Journal of International Relations and Development, 17(3): 301-338

Purushothaman, U. (2010). Shifting Perceptions of Power: Soft Power and India's Foreign Policy. Journal of Peace Studies, 17 ( 2\&3): 1-16.

Rahman Md S, Sarker P K, Sadath Md N, Giessen, L. (2018): Policy changes resulting in power changes? Quantitative evidence from 25 years of forest policy development in Bangladesh. In: Land Use Policy, 70, 419-431. https://doi.org/10.1016/j.landusepol.2017.11.029

Rahman, Md. S., Sarker, P. K., Giessen, L. (2016): Power players in biodiversity policy: Insights from international and domestic forest biodiversity initiatives in Bangladesh from 1992-2013. In: Land Use Policy, 59, 386-401, http://dx.doi.org/10.1016/j.landusepol.2016.09.013 .

Rahman, Md. S., Giessen, L. (2016): The power of public bureaucracies: Forest-related climate change policies in Bangladesh. In: Climate Policy, 17 (7), 915-935. http://dx.doi.org/10.1080/14693062.2016.1197093

Rajan, M. G. (1997). Global environmental politics: India and the North-South politics of global environmental issues. New Delhi: Oxford University Press.

Rice, P., and Ezzy, D. (1999). Qualitative research methods: A health focus. Melbourne: Oxford University Press.

Rastogi, N, M. (2011). Winds of Change: India's Emerging Climate Strategy The International Spectator. Italian Journal of International Affairs, 46(2): 127 -141.

Sarker, P., Rahman, S., Giessen, L. (2017): Empowering state agencies through national and international community forestry policies in Bangladesh. In: International Forestry Review, 19 (1),

79-101. http://www.ingentaconnect.com/contentone/cfa/ifr/2017/00000019/00000001/art00007

Singer, B, Giessen, L (2017): Towards a donut regime? Domestic actors, climatization, and the hollowing-out of the international forests regime in the Anthropocene. In: Forest Policy and Economics, 79, 69-79, http://dx.doi.org/10.1016/j.forpol.2016.11.006.

Sahide, M.A., Nurrochmat, D.R., Giessen, L. (2015): The regime complex for tropical rainforest transformation: Analysing the relevance of multiple global and regional land use regimes in 
Indonesia. In: Land Use Policy, $47 \quad$ (2015), $408-425$. http://dx.doi.org/10.1016/j.landusepol.2015.04.030

Schoene, D.H.F. and Bernier, P.Y (2011). Adapting forestry and forests to climate change: A challenge to change the paradigm. Forest Policy and Economics, 24:12-19. doi:10.1016/j.forpol.2011.04.007

Sengupta, S. (2012). International climate negotiations and India's role. In N. K. Dubash (Ed.), Handbook of climate change and India: Development, politics and governance (pp. 101-117). New York, NY: Earthscan.

Skak, M. (2011). The BRIC Powers as Actors in World Affairs: Soft Balancing or ... ? Paper presented at the IPSA-ECPR Joint Conference, Sao Paulo, February 16 to 19, 2011.

Snidal, D, (1991a). Relative Gains and the Pattern of International Cooperation. American Political Science Review, 85: 701-26.

Snidal, D, (1991b). International Cooperation among Relative Gains Maximizers. International Studies Quarterly, 35: 387-402.

Stripple, J. (2006). Rules for the environment: Reconsidering authority in global environmental governance. European Environment, 16(5), 259-264.

Stuenkel, O. (2010). The Case for Stronger Brazil-India Relations. Indian Foreign Affairs Journal, 5(3): 290-304.

Sud, R., Sharma, J.V., Bansal, A.K., (2012). International REDD+ architecture and its relevance for India. New Delhi: Ministry of Environment and Forests and TERI.

Tan. C. (2014). Global governance and the rise of the South. Retrieved from https://warwick.ac.uk/newsandevents/knowledge/socialscience/economicgrowthinternatio nalpower/

Thomann, E. (2015). Customizing Europe: transposition as bottom-up implementation. Journal of European Public Policy, 22(10), 1368-1387.

Vihma, A. (2011). India and the global climate governance: between principles and pragmatism. Journal of Environment \& Development, 20(10): 1-26.

Volger, J and H. R. Stephan. 2009. The embeddedness of the Earth system Governance in the international political system: Towards a Geopolitics of Climate Change. Paper presented at the Amsterdam Conference on the Human Dimensions of Global Environmental Change, Amsterdam, The Netherlands, 2-4 December, 2009. https://www.researchgate.net/publication/237233822_The_Embeddedness_of_Earth_Syst em_Governance_in_the_International_Political_System_Towards_a_Geopolitics_of_Climat e Change

Vibert, F. (2008). Soft Power and International Rule-Making. Friedrich Neumann Stiftung Liberales Institut, Occasional Paper 43, 2008, accessed on 15 March 2012 http://www.fnfkorea.org/uploads/document/OC43_Vibert.pdf

Wagner, C. (2010). India's Soft Power: Prospects and Limitations. India Quarterly: A Journal of International Affairs, 66(4): 333-342.

Wagner, C. (2005). From Hard Power to Soft Power? Ideas, Interaction, Institutions, and Images in India's South Asia Policy. 26, South Asia Institute, University of Heidelburg, March 2005, accessed March, 2011www.ub.uni-heidelberg.de/archiv/5436

Wibowo, A, Giessen, L (2015): Absolute and relative power gains among state agencies in forestrelated land use politics: The Ministry of Forestry and its competitors in the REDD+ Programme and the One Map Policy in Indonesia. Land Use Policy, 49, 131-141. http://dx.doi.org/10.1016/j.landusepol.2015.07.018

Willetts, P. (2001). Transnational Actors and International Organizations in Global Politics. In Baylis, J. B. and Smith, S. (eds.) (2001) The Globalisation of World Politics. Oxford and New York: Oxford University Press, second edition. pp. 356-383. 